\title{
Vestibular semicircular canal epithelium of the rat in culture on filter support: polarity and barrier properties
}

Received: 19 July 1998 / Received after revision: 10 December 1998 / Accepted: 18 December 1998

\begin{abstract}
The inner ear of mammals contains the vestibular apparatus which is involved in the maintenance of posture and balance. The tubular structure of the apparatus is bathed by the potassium-rich endolymph and sodium-rich perilymph in the luminal and abluminal compartments, respectively. The luminal compartment is lined by a continuous epithelium with islets of receptor organs, which separates the luminal from the abluminal compartment. The present work focuses on the epithelium, without the receptor organs, and shows that it can be reconstituted in culture. The epithelium from 4-day-old Wistar rats was grown on microporous membranes. High transepithelial electrical resistances $\left(4000-6000 \Omega \cdot \mathrm{cm}^{2}\right)$ were achieved after 4-8 days in culture. The epithelium was characterized by the presence of cytokeratin, ZO-1 protein, occludin, and the presence of tight junctions and kinocilia. The transepithelial resistance of the cell monolayer withstood endolymph/perilymph dual bathing when the apical pole of the cells was in contact with endolymph, but collapsed in the reverse configuration. Weak but statistically highly significant basal to apical rubidium $\left({ }^{86} \mathrm{Rb}\right)$ transport was observed. These findings show that this epithelium maintains its in vivo polarity and could enhance the potassium composition of endolymph up to maturity. This new culture model, in which dual bathing is possible, should enable further in vitro studies of the sensory vestibular epithelia.
\end{abstract}

Key words Electron microscopy · Epithelium . Immunocytochemistry $\cdot$ Ion transport · Labyrinthine fluids $\cdot$ Semicircular canals

P.G. Milhaud ( ) M.-T. Nicolas · S. Bartolami · A. Sans Université Montpellier II, INSERM U.432, CC089,

Neurobiologie et développement du système vestibulaire,

Place Eugène Bataillon, F-34095 Montpellier cedex 5, France

e-mail: pmilhaud@crit.univ-montp2.fr

Tel.: +33-04-67144879

Fax: +33-04-67143696

M.-T. Cabanis

Laboratoire de chimie analytique et toxicologie,

Université Montpellier I, 15 avenue Flahault,

F-34000 Montpellier, France

\section{Introduction}

The inner ear comprises the cochlea and the vestibular system, which are involved in hearing and balance, respectively. The vestibular system is a complex tubular structure with two maculae: the utricule and saccule, and three cristae ampullari, anastomosed to canals, three of which are the semicircular canals [12]. The outer surface of the vestibular system is covered by a mesenchymatous sheath and is immersed in the $\mathrm{Na}^{+}$-rich perilymph, which has a similar ionic composition to plasma. The luminal surface, bathed with endolymph, is lined by an epithelium that differentiates into five neurosensory organs located in the cavities. The sensory epithelia contain two types of cells: sensory hair cells and supporting cells. The sensory epithelia of the utricule and ampullae are surrounded by cells, named dark cells, involved in the secretion of endolymph which is poor in $\mathrm{Na}^{+}$and $\mathrm{Ca}^{2+}$ and rich in $\mathrm{K}^{+}[7,10,15,28]$.

Sensory epithelial cells and dark cells have received considerable attention, whereas the epithelial cells lining the semicircular canals have not been the focus of much research. Consequently, little is known about the function of this semicircular canal epithelium. This epithelium develops a huge surface of contact with the endolymph on one side and with the perilymph on the other. It is not clear whether the semicircular epithelium in mammals has only a passive role of containing the endolymph, as documented for the frog [7], or whether it performs particular biochemical functions.

To address this question, we have established an in vitro model by growing semicircular epithelium cells on filter support. In the present paper, we evaluate whether the semicircular epithelium in culture is a model that closely simulates the in vivo epithelium. We demonstrate that it is possible to grow semicircular epithelium in Transwell chambers. These chambers are designed to study cell polarity $[5,11]$ and allow access to the basal and apical compartments $[17,22]$. The cells in the semicircular epithelium culture are homogeneous, have a high electrical resistance, and have the morphological 
characteristics of cells in situ. Furthermore, their functional polarity is documented by dual endolymph and perilymph bathing of the epithelium, and also by transepithelial basal-to-apical ${ }^{86} \mathrm{Rb}$ transport.

\section{Materials and methods}

\section{Culture}

Dissection and enzymatic treatments were performed in MEM (Gibco, Life Technologies, France) buffered with HEPES [4-(2hydroxyethyl)-1-piperazine ethanesulphonic acid] (Sigma). Fourday-old Wistar rats were decapitated after anesthesia and the semicircular canals were removed from their bony canals. The utricles, saccules and ampullae were removed. The semicircular canals were incubated in collagenase type IV (Sigma) and dispase grade II (Boehringer Mannheim, Meylan, France) and DNase (Sigma) $\left(1 \mathrm{mg} / \mathrm{ml}\right.$ each) at $37^{\circ} \mathrm{C}$. After $20 \mathrm{~min}$ of incubation, collagenase and dispase $(1 \mathrm{mg} / \mathrm{ml}$ each) were added and incubation proceeded for a further $20 \mathrm{~min}$. The tissues were then pipetted up and down to free the pieces of semicircular epithelium from their connective sheath, and the pieces of epithelium were set aside. Finally, incubation with trypsin $(0.125 \%)$ for 10 min fragmented the epithelium, and pieces were then seeded in Transwell-clear cell culture chambers (Costar, Cambridge, Mass., USA). On the bottom of the chambers, there is a permeable polyester filter membrane of 0.4 $\mu \mathrm{m}$ pore size $\left(1.6 \times 10^{6}\right.$ pores $\left./ \mathrm{cm}^{2}\right)$ and $6.5 \mathrm{~mm}$ diameter. The cells were grown in DMEM glucose (1 g/l, Gibco) enriched with fetal bovine serum $5 \%(\mathrm{v} / \mathrm{v})$, penicillin $(100 \mathrm{units} / \mathrm{ml})$ and streptomycin $(100 \mu \mathrm{g} / \mathrm{ml})$. Each chamber contained material from one animal. The seeded Transwell chambers were inserted in a 24 -well cluster plate. The Transwell chambers contained $150 \mu \mathrm{l}$ culture medium (inner/apical compartment) and the wells had $700 \mu \mathrm{l}$ of medium (outer/basolateral side). The cell monolayers were incubated at $37^{\circ} \mathrm{C}$ in a $5 \% \mathrm{CO}_{2}$ atmosphere with saturated humidity and were fed with fresh medium every 2 days. We counted cells from scanning micrographs of a 10-day-old culture and estimated that around $1 \times 10^{5}$ cells covered the microporous membrane.

\section{Transmission electron microscopy}

Small pieces of semicircular canals and monolayers of semicircular epithelium grown on microporous membranes were fixed with $2 \%$ glutaraldehyde in $0.1 \mathrm{M}$ sodium cacodylate buffer, for $1.75 \mathrm{~h}$ at $4^{\circ} \mathrm{C}$; they were then washed in phosphate-buffered saline (PBS) overnight and post-fixed by $2 \% \mathrm{OsO}_{4}$ in phosphate buffer for 45 min at room temperature. After washing in distilled water, the samples were dehydrated in graded ethanol and embedded in epoxy resin (Araldite 502/EMbed 812) according to the manufacturer's protocol (Electron Microscopy Sciences, Fort Washington, Pa., USA). Sections were made with a diamond knife on an ultramicrotome (Reichert OMU3 Vienna, Austria), collected on Formwar-covered copper grids and stained with uranyl acetate and lead citrate before observation using an EM microscope (Jeol JEM 1200 Ex II). Observations were made at the electron microscopy facilities at the Université Montpellier II (France).

\section{Scanning electron microscopy}

Cell monolayers were washed with PBS ( $\mathrm{pH} 7.4)$ and fixed $(2 \%$ glutaraldehyde, $0.1 \mathrm{M}$ sodium cacodylate) at room temperature for $2 \mathrm{~h}$. The monolayers were carefully washed with buffer $(0.1 \mathrm{M}$ sodium cacodylate, $0.2 \mathrm{M}$ sucrose, $\mathrm{pH} 7.4)$, five times at $4^{\circ} \mathrm{C}$. The cells were post-fixed $\left(1 \% \mathrm{OsO}_{4}, 0.1 \mathrm{M}\right.$ sodium cacodylate, $0.1 \mathrm{M}$ sucrose) at room temperature for $1 \mathrm{~h}$ and washed with buffer $(0.2$ $\mathrm{M}$ sodium cacodylate, $\mathrm{pH}$ 7.4) and water. The cells were then dehydrated in up to $100 \%$ ethanol [18]. Critical point drying with liquid $\mathrm{CO}_{2}$ (CPD 030 dryer, Balzers) and the sputtering were per- formed according to standard methods. Observations were made with a scanning electron microscope (JSM-6300 F JEOL) at the Centre Regional d'Imagerie Cellulaire, the Université Montpellier I (France).

\section{5-Bromo-2'-deoxyuridine incorporation}

At 12 or $60 \mathrm{~h}$ after cell seeding, cultures were incubated with 5bromo-2'-deoxyuridine (BrdU) (Sigma, $100 \mu \mathrm{M}$ ) for $24 \mathrm{~h}$. The samples were fixed for immunocytochemical analysis.

\section{Immunocytochemistry}

Primary antibodies were directed to: BrdU (monoclonal from Sigma), cytokeratin (the pan-anti-cytokeratin antibodies were a mixture of monoclonal antibodies: clones C-11, PCK-26, CY-90, KS1A3, M20, A53-B/A2 from Sigma) [14], occludin (highly purified rabbit polyclonal from Zymed laboratories, San Francisco, Calif., USA) [2], Thy 1.1 (monoclonal clone MRC OX-7, Serotec, Realef, Paris, France) [16], ZO-1 protein (monoclonal from Chemicon International, Temecula, USA). The pertinent secondary antibodies were rhodamine or Texas red conjugated antibody (Jackson Immuno Research Laboratories, USA).

Culture preparation and labelling were performed at room temperature unless otherwise stated. Preparations of cultures prior to labelling were performed as follows. For BrdU, cells were fixed with ethanol $100 \%$ (30 $\mathrm{min}$ at $4^{\circ} \mathrm{C}$ ) and rehydrated in PBS. The DNA was denatured with hydrochloric acid $\left(2 \mathrm{M}, 1 \mathrm{~h}, 37^{\circ} \mathrm{C}\right)$ which was neutralized with borate buffer [30]. For cytokeratin and Thy 1, monolayers were rinsed with buffer A (50 mM Tris, 260 $\mathrm{mM}$ sodium chloride, $\mathrm{pH} 7.4$ ) for $5 \mathrm{~min}$ and fixed with $4 \%(\mathrm{w} / \mathrm{v})$ paraformaldehyde in PBS for $30 \mathrm{~min}$. The monolayers were rinsed and the non-specific binding sites were saturated by the addition of $10 \%$ goat serum in buffer $\mathrm{B}(50 \mathrm{mM}$ Tris, $\mathrm{pH} 7.4)$ or $0.5 \%$ (w/v) bovine serum albumin (BSA) in PBS for $1 \mathrm{~h}$. At this stage, the cells were permeabilized by supplementing buffer B with $0.1 \%$ Triton X-100 for $1 \mathrm{~h}$ and rinsed. For the ZO-1 protein, cultures were prepared according to a method described by Balda et al. [6] and started by a permeabilization with $0.2 \%$ Triton X-100 in buffer C (100 mM KCl, $3 \mathrm{mM} \mathrm{MgCl} 2,1 \mathrm{mM} \mathrm{CaCl}_{2}, 200 \mathrm{mM}$ sucrose, $10 \mathrm{mM}$ HEPES, pH 7.1) (2 min on ice). Fixation was carried out with $95 \%$ ethanol $\left(0^{\circ} \mathrm{C}, 30 \mathrm{~min}\right)$ followed by rehydration in PBS Non-specific binding sites were saturated with buffer D $(0.5 \%$ BSA, $10 \mathrm{mM}$ glycine, $0.05 \%$ azide, in PBS). For occludin localization, the preceding method was used with modifications. First, the monolayers were fixed with $4 \%$ paraformaldehyde in PBS for $15 \mathrm{~min}$. After rinsing, the cells were permeabilized as described above, then the cells were rinsed with PBS. Non-specific binding sites were saturated with buffer D.

Labelling with primary and secondary antibodies was carried out with a $1 / 100$ dilution, except for anti-occludin $(4 \mu \mathrm{g} / \mathrm{ml})$ and anti-ZO-1 protein, which were labelled at 1/1000 dilution. It was routinely verified that the secondary antibodies were exclusively reactive with the respective primary antibody. Finally, all the labelled monolayers were rinsed in PBS, mounted in Fluorsave reagent (Calbiochem, France) and observed by confocal microscopy (BioRad MRC 1024).

Transepithelial electrical resistance and voltage measurements

Measurements were performed under sterile conditions with an epithelial voltohmmeter (EVOM) fitted with an Endohm-6 chamber (World Precision Instruments, Aston, UK). Electrical resistance measurements were carried out with DMEM in the Endohm chamber. To express the results as $\Omega \cdot \mathrm{cm}^{2}$, the resistance $\left(R_{\mathrm{T}}\right)$ of DMEM plus membrane support (around $140 \Omega$ ) was subtracted from the resistance across the epithelium and multiplied by 0.33 $\mathrm{cm}^{2}$ (i.e. the effective epithelium area). The EVOM was very stable and sensitive up to $20,000 \Omega$. Voltage measurements were performed in the presence of DMEM in both compartments of the 
Table 1 Composition of reconstituted endolymph and perilymph. The solutions were adjusted to $\mathrm{pH} 7.4$ and osmolarity to 303 mosmol/l. DMEM* is DMEM medium deprived of salts, glutamine and $\mathrm{NaHCO}_{3}$ (BioMedia, Boussens, France)

\begin{tabular}{lcc}
\hline Solutions & Endolymph & Perilymph \\
\hline $\mathrm{NaCl}$ & $1 \mathrm{mM}$ & $141 \mathrm{mM}$ \\
$\mathrm{KCl}$ & $151.4 \mathrm{mM}$ & $7.4 \mathrm{mM}$ \\
$\mathrm{Mg}$ acetate & $0.03 \mathrm{mM}$ & $1 \mathrm{mM}$ \\
$\mathrm{CaCl}_{2}$ & $0.03 \mathrm{mM}$ & $0.7 \mathrm{mM}$ \\
$\mathrm{K}_{2} \mathrm{HPO}_{4}$ & $1.6 \mathrm{mM}$ & $1.6 \mathrm{mM}$ \\
$\mathrm{KH}_{2} \mathrm{PO}_{4}$ & $0.4 \mathrm{mM}$ & $0.4 \mathrm{mM}$ \\
$\mathrm{Glutamine}_{\text {Glutamic acid }}$ & $1 \mathrm{mM}$ & $2 \mathrm{mM}$ \\
DMEM & $0.85 \mathrm{mM}$ & $0.17 \mathrm{mM}$ \\
FBS & $100 \mathrm{ml} / 1$ & $200 \mathrm{ml} / 1$ \\
HEPES & $10 \mathrm{ml} / 1$ & $0.4 \mathrm{ml} / 1$ \\
\hline
\end{tabular}

Transwell chambers. Changing the medium modified the epithelial electrical resistance. The mean short-circuit current equivalent $\left(I_{\text {eq }}\right)$ was computed from the linear regression voltage as a function of resistance. All experiments were carried out after monolayers reached their maximum electrical resistance: $4000-6000 \Omega \cdot \mathrm{cm}^{2}$ after 4-8 days in culture.

Epithelium dual bathing with endolymph- and perilymph-like media

The compositions of endolymph and perilymph (Table 1) were estimated from the literature [28, 29]. The eight Transwell chambers were divided into two groups of four Transwell chambers, such that the resistances of the monolayers between groups were comparable. The culture medium was replaced by the different media to be tested. After 2 days of incubation, electrical resistances were assessed without draining off the apical medium and with a pool of the relevant basal medium.

Ion transport and Lucifer yellow permeability

The transepithelial transports of ${ }^{22} \mathrm{Na}(13 \mathrm{GBq} / \mathrm{mg}, 0.28 \mu \mathrm{g} / \mathrm{ml}$, Amersham, Les Ulis, France) and ${ }^{86} \mathrm{Rb}(22 \mathrm{MBq} / \mathrm{mg}, 1.66 \mathrm{mg} / \mathrm{ml}$, Amersham) were checked at the following concentrations: $18.5 \mathrm{mBq} / \mathrm{ml}$ for ${ }^{22} \mathrm{Na}$ and $111 \mathrm{mBq} / \mathrm{ml}$ for ${ }^{86} \mathrm{Rb}$. We assumed that the tracers used were effective for $\mathrm{Na}^{+}$and $\mathrm{K}^{+}$. Both compartments of the Transwell chambers contained the usual culture medium. The electrical resistances of epithelia were measured and, as indicated for the dual bathing experiments, eight monolayers were organized and used. The radioelement was distributed in the apical compartment for one group of Transwell chambers and the basal for the other group. After $1 \mathrm{~h}$ of incubation at $37^{\circ} \mathrm{C}$, samples $(100 \mu \mathrm{l})$ were taken from each compartment and counted for 10 min (scintillation liquid: Ready Safe, Beckman, France). The ionic permeability, $P$, expressed in $\mathrm{cm} / \mathrm{min}$, was computed by the following equation

$$
P=\frac{Q}{S \times T \times C}
$$

where $Q$ is the total number of counts per minute (cpm) diffusing toward the non-inoculated compartment, $S$ is the epithelium surface area $\left(0.33 \mathrm{~cm}^{2}\right), T$ is the incubation time expressed in minutes and $C$ is the concentration $(\mathrm{cpm} / \mathrm{ml})$ of the radioactive element inoculated. Net transport was determined by the difference between the apical to basal $(\mathrm{A} \rightarrow \mathrm{B})$ and basal to apical $(\mathrm{B} \rightarrow \mathrm{A})$ permeabilities.

We used Lucifer yellow (Sigma), a cell non-permeant fluorescent molecule (mol. wt. $443.5 \mathrm{Da}$ ), to assess paracellular permeability. The technique and calculations were identical to those de- scribed above. The concentration of Lucifer yellow in DMEM was $0.19 \mathrm{mM}$. The fluorescence was measured by a spectrofluorimeter (Hitachi F-2000, ScienceTec, France).

Quantitative determination of $\mathrm{K}^{+}$and $\mathrm{Na}^{+}$concentrations

Potassium and sodium were analysed by inductive coupling plasma atomic emission spectroscopy (ICP/AES) [23].

Statistical analysis

Data were statistically analysed by Student's $t$-test and analysis of variance (ANOVA). Data were expressed as mean \pm standard deviation (SD) ( $n=$ number of samples) [25].

\section{Results}

Isolation and culture of epithelium

The following factors allowed us to obtain pure semicircular canal epithelium. First, enzymatic treatment of semicircular canals enabled the physical separation of the connective sheath enveloping the epithelium; second, the epithelium looked brighter than pieces of the connective sheath, which made it easier to separate them under the dissecting microscope.

To determine the extent of cell multiplication during the establishment of monolayers, we labelled BrdU after incorporation in DNA. Immunolabelling of nuclei, observed by confocal microscopy, indicated that many cells were labelled between $12 \mathrm{~h}$ and $36 \mathrm{~h}$ and only a few nuclei between $60 \mathrm{~h}$ and $84 \mathrm{~h}$ after seeding the cells (data not shown).

To determine the best culture support, we compared epithelia grown in "Transwell-clear" and "Transwell-collagen" coated chambers. Up to the 10th day of culture, the paracellular permeability to Lucifer yellow was higher with Transwell-collagen than with Transwell-clear chambers (data not shown), and therefore we used Transwell-clear chambers throughout this work.

\section{Culture homogeneity}

To assess the cellular homogeneity of the cultures, cell monolayers were labelled either with anti-pan-cytokeratin antibodies or anti-Thy 1.1 [30]. Figure 1a shows the density of the epithelium labelled with anti-pan-cytokeratin antibodies. This indicated that the cultures were homogeneous, as confirmed by Fig. 1b which presents rare fibroblasts.

To further characterize the epithelial monolayers, we checked for the presence of occludin $[1,2]$ and ZO-1 protein [30], both markers of tight junctions. Both showed labelling at the cell peripheries (Fig. 2a, b). 


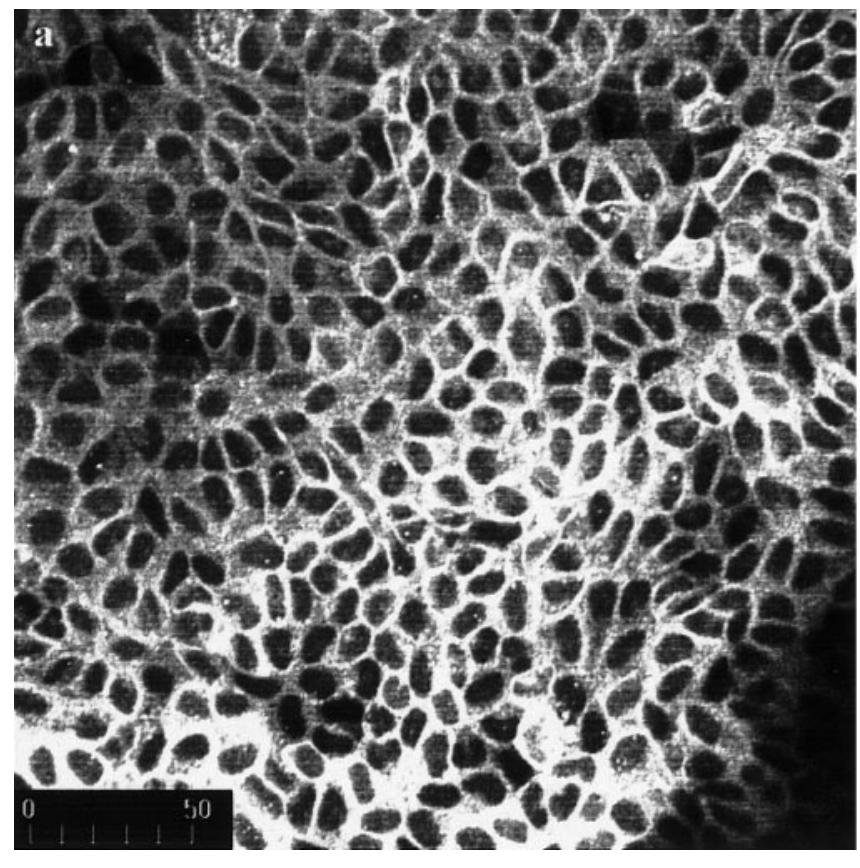

Fig. 1a, b Cytokeratin and Thy 1 immunofluorescence labelling of semicircular epithelium in culture in Transwell chambers. Sixteen-day-old cultures were fixed and labelled as described in Materials and methods. a With a mixture of monoclonal anti-pancytokeratin antibodies, a "cobblestoned" epithelium was visible. b The culture was labelled with monoclonal anti-Thy 1.1 antibodies. Only rare contaminating fibroblastic cells were labelled. Bars: $50 \mu \mathrm{m}$

\section{Morphological polarity of the cells in culture}

Electron microscopy observations of semicircular canals of 4-day-old rats showed that the cells were flat, around 2-3 $\mu \mathrm{m}$ thick, with a basal membrane and a collagen layer separating the epithelial canal cells from the connec-

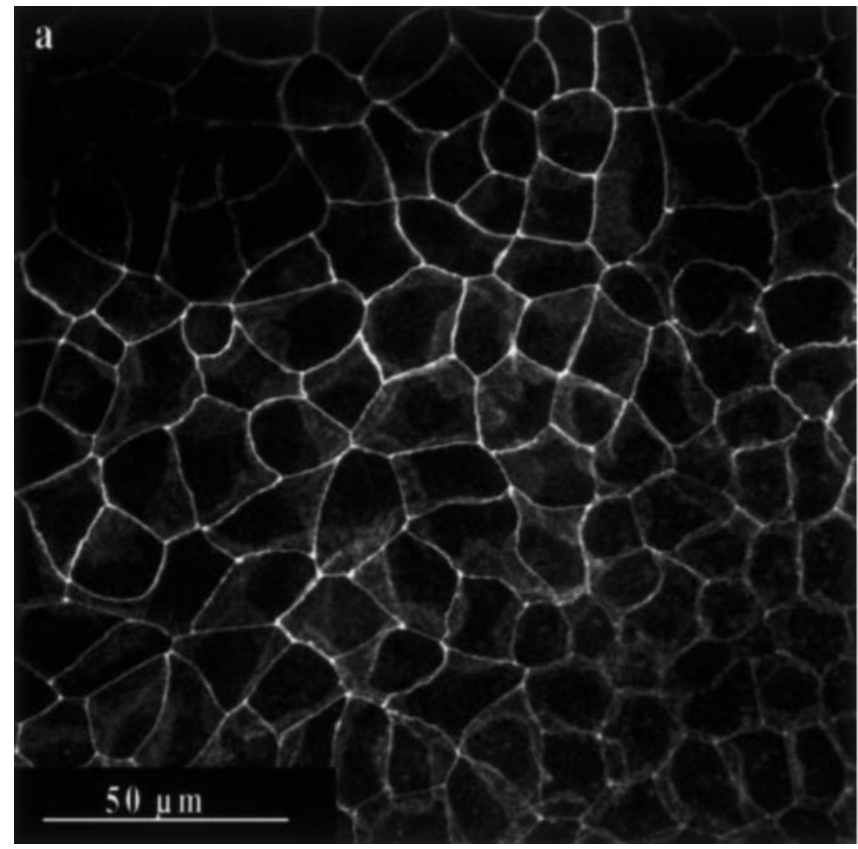

b

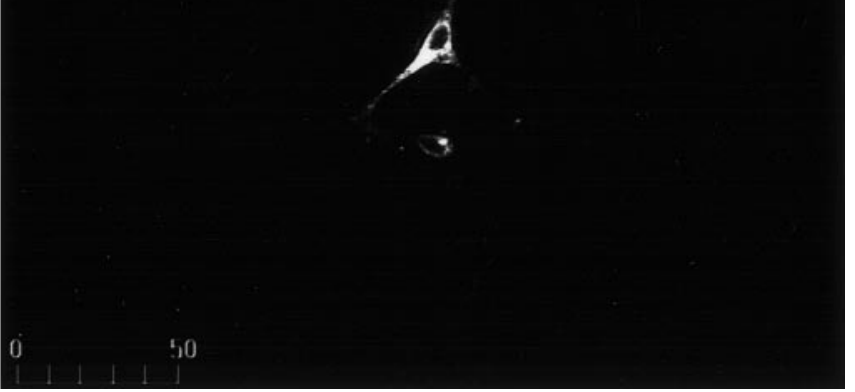

tive tissue (Fig. 3a). Microvilli were observed on the luminal side. The cells were intermingled, with luminal tight junctions and desmosomes. Scanning electron microscopy observations indicated that the cells were polygonal, exhibited a kinocilium and their surfaces were covered with microvilli (Fig. 4a).

As also noted in situ, cells cultured in Transwell chambers showed tight junctions (Fig. 3b) and were flat,

Fig. 2a, b Occludin and ZO-1-protein immunofluorescence labelling of semicircular epithelium in culture in Transwell chambers. Fifteen-day-old cultures were fixed and labelled as described in the Materials and methods: a with anti-occludin antibodies; $\mathbf{b}$ with anti-ZO-1 antibodies. Both pictures showed labelling of the cell peripheries. Bars: $50 \mu \mathrm{m}$

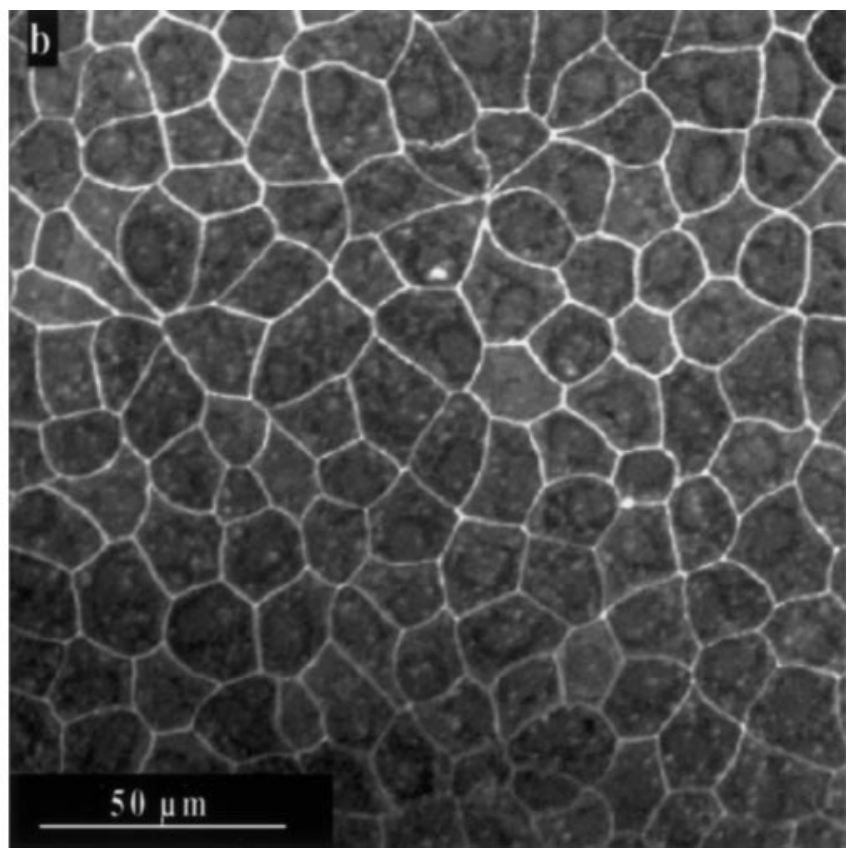



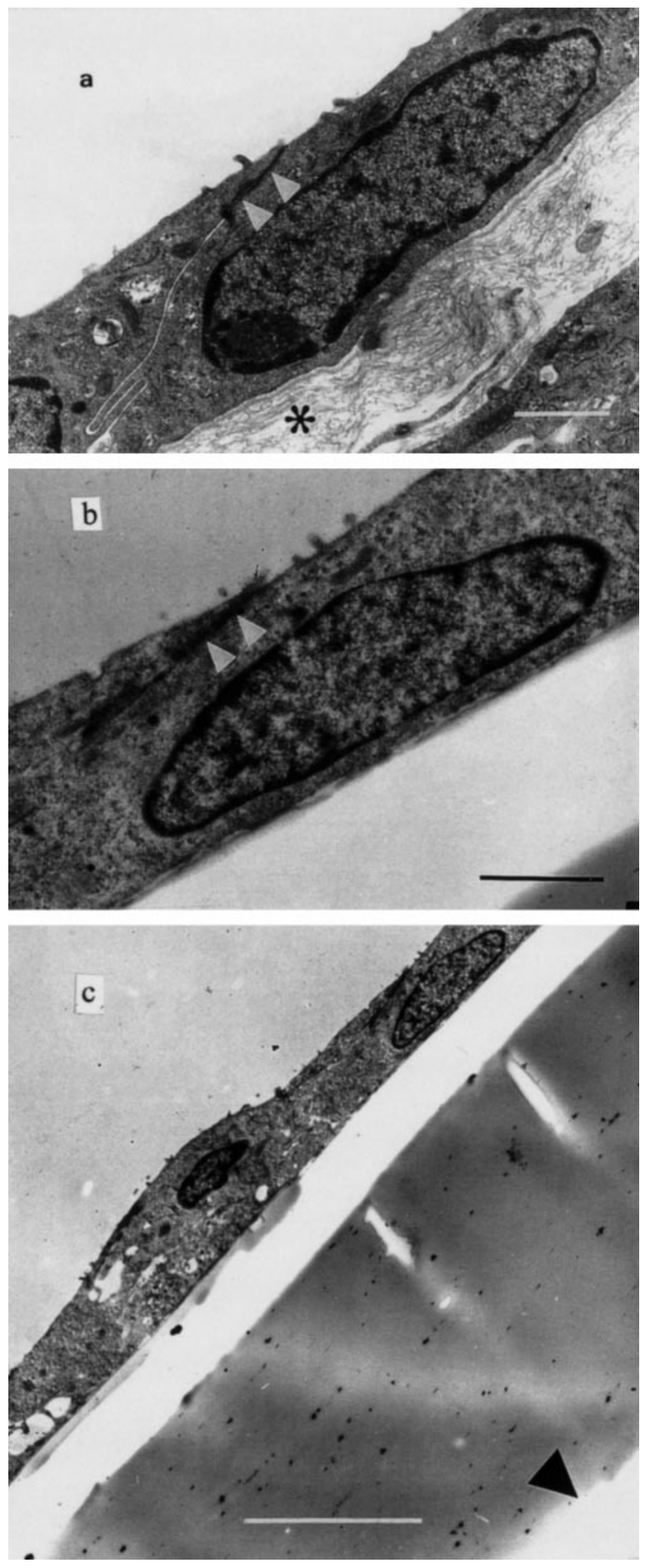

Fig. 3a-c Transmission electron micrograph of semicircular epithelium cells. a Section of semicircular canal from a 4-day-old rat: the collagen layer (asterisk) and tight junctions (open arrowheads) are visible. b, c Semicircular epithelium on Transwell chambers at 4 days of culture. b Tight junctions (open arrowheads) are visible. The section separated the epithelium from its substratum. c There are no cells below the microporous membrane (solid arrowhead). Bars: $1 \mu \mathrm{m}(\mathbf{a}, \mathbf{b}), 5 \mu \mathrm{m}(\mathbf{c})$ polygonal, covered with microvilli and a kinocilium was present on most of the cells (Fig. 4b). Few domes (around 30 domes $/ \mathrm{cm}^{2}$ less than 50 cells/dome) were observed and no cells were found on the reverse side of the filter membrane (Fig. 3c).

\section{Transepithelial electrical resistance and voltage}

The electrical resistance of the monolayers was recorded every 2nd or 3rd day for 1 month (Fig. 5). The maximum resistance was observed after 4-8 days and then held steady at $3000-5000 \Omega \cdot \mathrm{cm}^{2}$ or slowly dropped, depending on the extent of experimental disturbances.

Monolayers showed an apical-negative transepithelial potential difference $\left(V_{\mathrm{T}}\right) 12$ days and 22 days after seeding the cells. $I_{\text {eq }}$ was computed from Ohm's law using $V_{\mathrm{T}}$ and transepithelial electrical resistance $\left(R_{\mathrm{T}}\right)$. The results were $R_{\mathrm{T}}=3294 \pm 618.5 \Omega \cdot \mathrm{cm}^{2}, V_{\mathrm{T}}=-3.95 \pm 0.983 \mathrm{mV}, I_{\text {eq }}=$ $1.4 \pm 0.9 \mu \mathrm{A} / \mathrm{cm}^{2}(n=6)$ (12th day); and $R_{\mathrm{T}}=3210 \pm 1682$ $\Omega \cdot \mathrm{cm}^{2}, V_{\mathrm{T}}=-2.98 \pm 1.91 \mathrm{mV}, I_{\mathrm{eq}}=1.11 \pm 0.2 \mu \mathrm{A} / \mathrm{cm}^{2}(n=8)$ (22th day).

As the extracellular calcium is essential for maintaining tight junction integrity [27], we checked the effect of ethylene bis(oxyethylene nitrilo)tetraacetic acid (EGTA), a calcium chelator. The electrical resistance was reduced instantly and dramatically after EGTA treatment (4 mM) in both compartments (data not shown). This observation bore out the assumption that apical junctions of the semicircular epithelium are tight junctions.

\section{Dual bathing with endolymph and perilymph}

In the same experiment, monolayers were incubated with the endolymph and perilymph, with three dual bathing combinations. The combinations were: (1) DMEM enriched only with $1 \%$ serum (due to the low amount of serum in the reconstituted endolymph and perilymph) in both compartments as control, (2) endolymph- and perilymph-like medium in the apical and basal compartments respectively, and (3) the reverse configuration. After 2 days of incubation, the electrical resistances were measured. The results of one of the experiments are presented in Table 2. First, reducing the serum from 5\% to $1 \%$ of the DMEM was not critical for $R_{\mathrm{T}}$. Secondly, opposing the endolymph and perilymph reduced resistances, and 2 days later the high resistance recovered. The effect was dramatic when endolymph bathed the basal compartment, i.e. the resistance disappeared completely.

\section{Transepithelial ion transports}

The transepithelium transport of $\mathrm{K}^{+}$and $\mathrm{Na}^{+}$between compartments containing the culture medium was investigated at the plateau of maximum electrical resistance. Three independent experiments were pooled and analysed by two-way ANOVA (Table 3 ). The ${ }^{22} \mathrm{Na}$ permeabilities exhibited lower values than ${ }^{86} \mathrm{Rb}$ and no significant 


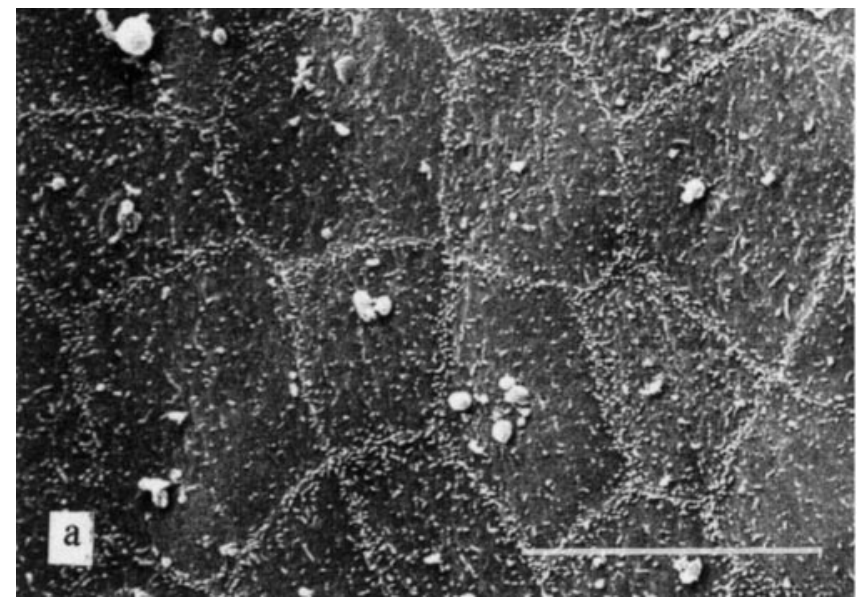

Fig. 4a, b Scanning electron micrograph of semicircular canal epithelium in situ and in culture. a Apical side of polygonal microvilli-bearing semicircular canal cells from a 4-day-old rat. b Epithelium at 10 days of culture showing microvilli and kinocilia. Bars: $10 \mu \mathrm{m}$

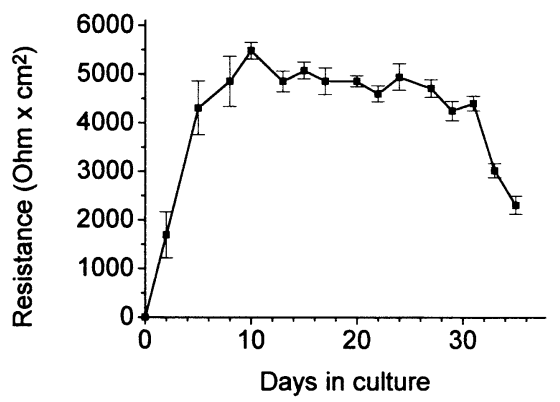

Fig. 5 Transepithelial resistance of the semicircular epithelium throughout the culture period. Transwell chambers were seeded and resistance measurements carried out every 2 nd or 3 rd day, as described in Materials and methods. Data points are means \pm SD $(n=8)$

difference was detected by ANOVA $(P>0.05) .{ }^{86} \mathrm{Rb}$ permeabilities $(\mathrm{B} \rightarrow \mathrm{A})$ were found to be highly significant $(P<0.01)$.

To confirm these observations, two identical experiments were carried out and their results were pooled for ANOVA. In each experiment, the media of apical and basal compartments of four Transwell chambers were

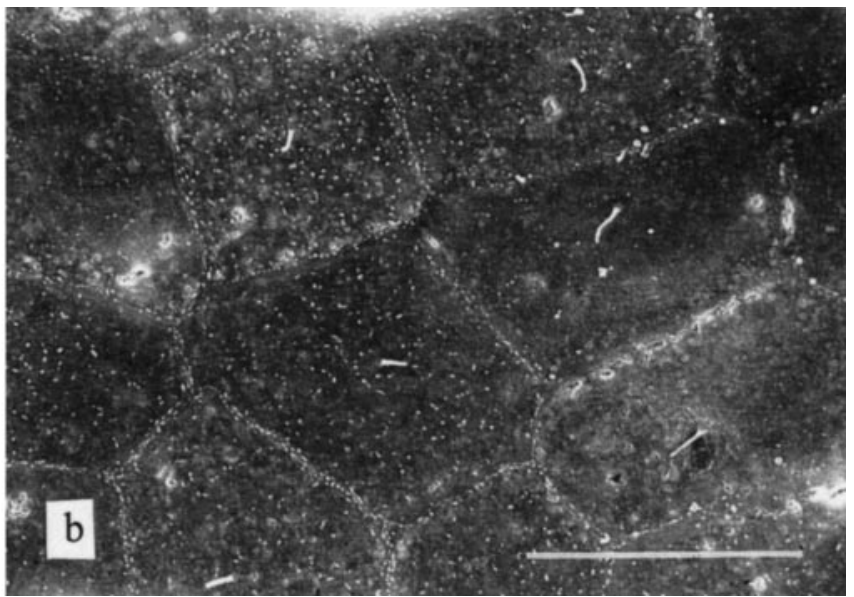

Table 2 Transepithelial resistance changes during dual bathing in culture. Either DMEM (with only 1\% serum, as control) or different media (endolymph- and perilymph-like) faced the cells in culture. Monolayers were incubated for $48 \mathrm{~h}$. At the start, apical and basal compartments both contained culture medium (DMEM and $5 \%$ serum). The results of two experiments were pooled and are expressed as $\Omega \cdot \mathrm{cm}^{2}( \pm \mathrm{SD})$. (Endo/Perilymph Endolymph in the apical compartment and perilymph in the basal compartment, Peri/Endolymph perilymph in the apical compartment and endolymph in the basal compartment)

\begin{tabular}{lc}
\hline Experimental conditions & Electrical resistance $\left(\Omega \cdot \mathrm{cm}^{2}\right)$ \\
\hline Mean resistance at the start & $4962 \pm 1653(n=16)$ \\
and after 48 h incubation in: & $3615 \pm 1843(n=4)$ \\
DMEM/DMEM & $1812 \pm 945(n=6)$ \\
Endo/Perilymph & $8 \pm 11(n=6)$ \\
Peri/Endolymph & \\
\hline
\end{tabular}

analysed by ICP/AES for $\mathrm{Na}^{+}$and $\mathrm{K}^{+}$after 2 days of incubation. In each experiment, four control samples of medium were also analysed and entered the ANOVA. The measured $\mathrm{K}^{+}$concentrations were: apical $275.5 \pm 14.04 \mathrm{mg} / \mathrm{l}, n=8$; basal $227.4 \pm 6.6 \mathrm{mg} / \mathrm{l}, n=8$; control $233.7 \pm 5.0 \mathrm{mg} / \mathrm{l}, n=8$. The ANOVA indicated that the apical concentration differed markedly from the basal and control media $(P<0.005)$. A Student's $t$-test compared the results obtained by permeability and analysis methods: ${ }^{86} \mathrm{Rb}$ transport, $0.016 \pm 0.010 \mu \mathrm{mol} / \mathrm{cm}^{2}$ per hour $(n=6)$ (values converted from Table 3 ), and $\mathrm{K}^{+}$transport, $0.032 \pm 0.0064 \mu \mathrm{mol} / \mathrm{cm}^{2}$ per hour $(n=16)$, were not statistically different $(P>0.05)$. Concerning ${ }^{22} \mathrm{Na}$, its higher
Table 3 Estimation of ion transepithelial transport. The transepithelial transport of ${ }^{22} \mathrm{Na}$ and ${ }^{86} \mathrm{Rb}$ was measured after $1 \mathrm{~h}$ of incubation, as indicated in Materials and methods. The mean resistance values for the sets of Transwell chambers with their epithelium are indicated. The mean transfer values are indicated \pm SD. A highly significant difference was noted for ${ }^{86} \mathrm{Rb}$ between $(\mathrm{A} \rightarrow \mathrm{B})$ and $(\mathrm{B} \rightarrow \mathrm{A})$

\begin{tabular}{|c|c|c|c|}
\hline & & $\begin{array}{l}\text { Permeability } \\
\left(\times 10^{-5} \mathrm{~cm} / \mathrm{min}\right)\end{array}$ & $\begin{array}{l}\text { Resistance of } \\
\text { monolayers }\left(\Omega \cdot \mathrm{cm}^{2}\right)\end{array}$ \\
\hline${ }^{22} \mathrm{Na}$ transport & $\begin{array}{l}(\mathrm{A} \rightarrow \mathrm{B}) \\
(\mathrm{B} \rightarrow \mathrm{A})\end{array}$ & $\begin{array}{l}3.48 \pm 0.974(n=12) \\
1.46 \pm 0.833(n=12)\end{array}$ & $\begin{array}{l}5930 \pm 284.4(n=8) \\
-\end{array}$ \\
\hline $\begin{array}{l}\text { Net transfer: } \\
{ }^{22} \mathrm{Na}(\mathrm{A} \rightarrow \mathrm{B})\end{array}$ & & $2.0 \pm 2.38(n=12)$ & - \\
\hline $86 \mathrm{Rb}$ transport & $\begin{array}{l}(\mathrm{A} \rightarrow \mathrm{B}) \\
(\mathrm{B} \rightarrow \mathrm{A})\end{array}$ & $\begin{array}{l}1.67 \pm 0.224(n=12) \\
6.01 \pm 2.672(n=12)\end{array}$ & $\begin{array}{l}5940 \pm 194.6(n=8) \\
-\end{array}$ \\
\hline $\begin{array}{l}\text { Net transfer: } \\
\quad{ }^{86} \mathrm{Rb}\end{array}$ & $(\mathrm{B} \rightarrow \mathrm{A})$ & $4.34 \pm 2.78^{* *}(n=12)$ & - \\
\hline
\end{tabular}


concentration limited the measurement sensitivity and the preliminary results were not consistent.

\section{Discussion}

Endolymph plays a mechanical and a biochemical role. In vivo, the hair of bundles of sensory cells of the ampullae are sensitive to the angular acceleration of endolymph, which is channelled by the semicircular canals. It is thought that the high $\mathrm{K}^{+}$concentration of endolymph is critical in driving the mechano-electrical transduction current into the cytosol of sensory hair cells. $\mathrm{K}^{+}$is thought to flow down according to its driving force from the endolymph into the hair cell cytosol, and then induce the depolarization that causes neurotransmitter release $[13,15]$. Studying the semicircular epithelium is interesting because of its resistance when its apical pole is exposed to a high $\mathrm{K}^{+}$concentration, a situation that is usually toxic for many cell types. Several characteristics had to be examined to establish a suitable in vitro cell model: (1) culture purity, (2) in situ morphology, (3) bioelectrical features, (4) survival under physiological conditions, and (5) expression of its biochemical functionality.

To curb the possible growth of fibroblasts, excess epithelial cells were seeded to cover the microporous membrane in a few days (3-4 days). Very few fibroblasts contaminated the monolayers, as confirmed by Thy 1 and cytokeratin immunolabelling. The reproducible high electrical resistance also demonstrated the low level of contamination with fibroblasts, which do not usually generate electrical resistance.

Immunolabelling of the cultures showed that they also express ZO-1 protein and occludin, which are proteins associated with tight junctions, demonstrating the epithelial nature of the cells in culture [1]. Both proteins form a web and are markers of polarity. The web limits the diffusion of ions and molecules between apical and basolateral membranes. The epithelium grown in Transwell chambers displayed the morphological polarity and features of a differentiated semicircular epithelium in situ. The scanning electron microscopy analysis indicated that microvilli were present and a kinocilium was found on most of the cells in culture as well as in situ [12]. The presence of kinocilia on rat epithelial endolymphatic duct in situ has also been reported $[19,20]$. The presence of tiny domes at maximum electrical resistance could not be explained. According to studies of other models, domes are blisters caused by basal liquid secretion from epithelium grown on impervious surfaces [9, 21]. As no cells were growing on the reverse side of the filter membrane, we wondered whether a number of pores might have been obstructed for some reason, thus creating small impervious areas.

Transmission electron microscopy showed that the semicircular epithelial cells were connected by desmosomes and apical links, probably tight junctions. Sections of epithelium in situ and in culture were comparable, except that the in situ cells were lying on a thick collagenlike layer. The cytoplasm and apical surfaces did not dis- play features of secretory cells or of cells performing high levels of liquid transport under either condition.

The presence of tight junctions is usually associated with electrical resistance. The resistance reached by the semicircular epithelium in culture $\left(4000-5000 \Omega \cdot \mathrm{cm}^{2}\right)$ was comparable to that of the MDCK type-I epithelial cell line grown on nitrocellulose or polycarbonate support [8]. Studies of different epithelial cells in culture indicate that more appropriate media or substratum modify resistance [8], or further the development of in vitro morphology and increase the ion transport capacity $[4,11]$. Unfortunately, the transepithelial electrical resistance of the in situ semicircular epithelium is not known, which prevents us from comparing in situ and in vitro resistances.

Another functional polarity observed in vivo was maintained in culture: the semicircular epithelium in culture had a measurable resistance when endolymph bathed its apical surface. In the experiments, the medium changes were performed without any graded adaptation. They indicated that epithelia maintained their characteristic apical and basolateral domains even in the presence of the same culture medium on both sides, suggesting that cell differentiation is independent of extracellular factors. This is supported by the fact that the electrical resistance collapsed when the endolymph medium was on the basal side in culture.

The events that abolished the electrical resistance when the endolymph bathed the basal medium are not known. Several working hypotheses can be considered. When the extracellular $\mathrm{K}^{+}$concentration is elevated by equimolar substitution of extracellular $\mathrm{KCl}$ for $\mathrm{NaCl}$, the product $\left[\mathrm{K}^{+}\right]_{0} \times\left[\mathrm{Cl}^{-}\right]_{\mathrm{o}}$ may increase and exceed the product $\left[\mathrm{K}^{+}\right]_{\mathrm{i}} \times\left[\mathrm{Cl}^{-}\right]_{\mathrm{i}}$. Accordingly, $\mathrm{K}^{+}$and $\mathrm{Cl}^{-}$ions would move into cells with water, and they would swell and die [31]. Another possibility is that the medium containing $153 \mathrm{mM} \mathrm{K}^{+}$and $1 \mathrm{mM} \mathrm{Na}{ }^{+}$makes the Na-K,ATPase (present at the basolateral membrane in situ [26]) stop functioning, thus disturbing many exchange or cotransport mechanisms (e.g. $\mathrm{Na}^{+} / \mathrm{H}^{+}$exchange or $\mathrm{Na}^{+}$-glucose cotransport) [24]. The active transport of $\mathrm{K}^{+}$and resistance measured after dual bathing for 2 days are not in line with the observations obtained in studies of the frog, showing that the endolymph/perilymph gradient collapses $4 \mathrm{~h}$ after ligating the semicircular canal [7]. The models are different (rodent versus frog), as are the experimental conditions.

The above functional polarity prompted us to investigate the $\mathrm{Na}^{+} / \mathrm{K}^{+}$exchange of the semicircular epithelium. The net transepithelial transports of ${ }^{22} \mathrm{Na}$ and ${ }^{86} \mathrm{Rb}$ (known to substitute for $\mathrm{Na}^{+}$and $\mathrm{K}^{+}$) were explored with the culture medium bathing apical and basolateral domains. The ${ }^{22} \mathrm{Na}$ net transport was not significant. The ${ }^{86} \mathrm{Rb}$ net transport was highly significant and directed towards the apical surface. If this finding were confirmed in vivo, it would suggest that the epithelium is involved in the elaboration of endolymph with dark cells. The epithelium grown in culture was from 4-day-old rats, an age where the $\mathrm{K}^{+}$concentration of endolymph is still increasing, thus reaching the adult level 8 days after birth for the rat [3]. It is currently unknown whether the observed 
$\mathrm{K}^{+}$transport would be inhibited if endolymph medium were present on the apical pole of the culture. Dual bathing and transepithelial transports underscored the functional polarity of the semicircular epithelium in culture.

In our experiment, the $\mathrm{K}^{+}$secretion (0.016-0.032 $\mu \mathrm{mol} \cdot \mathrm{cm}^{-2} \cdot \mathrm{h}^{-1}$ depending on the methods) was around 100-fold lower than the dark cell secretion rate: 2.1 $\mu \mathrm{mol} \cdot \mathrm{cm}^{-2} \cdot \mathrm{h}^{-1}$ measured in the gerbil utricle [15]. Caution is mandatory for interpretation, since the species are different (rat versus gerbil). However, for rat, it would be interesting to know exactly what surfaces are occupied by dark cells and the semicircular epithelium and to compare the importance of both transport systems during development (i.e. the first week after birth).

Previous results are supported by another observation concerning monolayer polarity, which also encourages further investigations. The apical-negative transepithelial potential difference indicated that other transepithelial transport mechanisms were involved, particularly anionic transport. The enzymatic equipment and ion transport systems or receptors of the in situ semicircular epithelium have not been fully investigated.

In summary, the present results indicate that the semicircular epithelium grown on microporous membrane provides a differentiated culture closely matching the in situ morphology with functional polarity. This is the first model of culture on microporous membrane enabling dual bathing with the endolymph and perilymph for studies of inner ear epithelium. In addition, the model is versatile enough to allow biochemical investigations or ion transport studies, such as the $\mathrm{K}^{+}$secretion presented here.

Acknowledgements Our thanks are due to Mrs Travo for technical assistance. We are grateful to Dr. Liautard and Dr. Marti (U431 INSERM) and their collaborators who offered free access to their laboratory and specific equipment. The authors are deeply indebted to Dr. Lenoir for advice and help and Dr. Lennan and Dr. Valmier for revising the manuscript. This work was made possible thanks to the support of the Institut National de la Santé et de la Recherche Medicale, the Centre National d'Etudes Spatiales (98) and the Direction des Recherches, Etudes et Techniques (95-061).

\section{References}

1. Anderson JM, Van Itallie CM (1995) Tight junctions and the molecular basis for regulation of paracellular permeability. Am J Physiol 269:G467-G475

2. Ando-Akatsuka Y, Saitou M, Hirase T, Kishi M, Sakakibara A, Itho M, Yonemura S, Furuse M, Tsukita S (1996) Interspecies diversity of the occludin sequence: cDNA cloning of human, mouse, dog, and rat-kangaroo homologues. J Cell Biol 133:43-47

3. Anniko M, Nordemar H (1980) Embryogenesis of the inner ear IV. Post-natal maturation of the secretory epithelia of the inner ear in correlation with the elemental composition in the endolymphatic space. Arch Otorhinolaryngol 229:281-288

4. Avella M, Ehrenfeld J (1997) Fish gill respiratory cells in culture: a new model for $\mathrm{Cl}^{-}$-secreting epithelia. J Membr Biol 56:87-97

5. Baghdiguian S, Verrier B, Marvaldi J, Fantini J (1992) Shortterm suramin treatment followed by the removal of the drug induces terminal differentiation of HT29-D4 cells. J Cell Physiol 150:168-174
6. Balda MS, Gonzalez-Marical L, Matter K, Cereijido M, Anderson JM (1993) Assembly of the tight junction: the role of diacylglycerol. J Cell Biol 123:293-302

7. Bernard C, Ferrary E, Sterkers O (1986) Production of endolymph in the semicircular canal of the frog "Rana esculenta". J Physiol (Lond) 371:17-28

8. Butor C, Davoust J (1992) Apical to basal surface area ratio and polarity of MDCK cells grown on different supports. Exp Cell Res 203:115-127

9. Corman B, Roy C, Roinel N, Rouffignac C de (1984) Fluid composition of basolateral space of kidney cells in culture and its modification by intracellular cAMP. Am J Physiol 246: C546-C550

10. Ferrary E, Sterkers O (1998) Mechanism of endolymph secretion. Kidney Int 53 [Suppl. 65]:S98-S103

11. Genestie I, Morin J-P, Vannier B, Lorenzon G (1995) Polarity and transport properties of rabbit kidney proximal tubule cells on collagen IV-coated porous membranes. Am J Physiol 269: F22-F30

12. Harada Y (1988) The vestibular organs. Nishimura, Kugler and Ghedini, Amsterdam

13. Hudspeth AJ (1989) How the ear's works work. Nature 341: 397-404

14. Lane EB, Alexander CM (1990) Use of keratin antibodies in tumors diagnosis. Semin Cancer Biol 1:165-179

15. Marcus NY, Marcus DC (1987) Potassium secretion by nonsensory region of gerbil utricle in vitro. Am J Physiol 253: F613-F621

16. Mason DW, Williams AF (1980) The kinetics of antibody binding to membrane antigens in solution and at the cell surface. Biochem J 187:1-20

17. Milton SG, Knutson VP (1990) Comparison of the function of the tight junctions of endothelial cells and epithelial cells in regulating the movement of electrolytes and macromolecules across the cell monolayer. J Cell Physiol 144:498-504

18. Pottu-Boumendil J (1989) Microscopie electronique. In: Techniques en... [series]. Les Editions INSERM, Paris, pp 17-21

19. Qvortrup K, Roostgaard J (1994) Ultrastructure of the epithelial cells of the endolymphatic duct in the rat. Acta Otolaryngol (Stockh) 114:30-39

20. Qvortrup K, Roostgaard J, Bretlau P (1995) Surface morphology of the endolymphatic duct in the rat: a scanning electron microscopy study. Ann Otolrhinollaryngol 104:120-126

21. Rabito CA, Tchao R, Valentich J, Leighton J (1980) Effect of cell-substratum interaction on hemicyst formation by MDCK cells. In vitro 16:461-468

22. Saito H, Yamamoto M, Inui K-I, Hori R (1992) Transcellular transport of organic cation across monolayers of kidney epithelial cell line LLC-PK 1 . Am J Physiol 262:C59-C66

23. Scood DA, West DM, Holler FJ (1988) Fundamentals of analytical chemistry, 5th edn. Saunders College, London

24. Skou JC, Esmann M (1992) The Na,K-ATPase. J Bioenerg Biomembr 24:249-261

25. Snedecor GW, Cochran WG (1968) Statistical methods, 6th edn. Iowa University Press, Ames

26. Spicer SS, Schulte BA, Adams JC (1990) Immunolocalization of $\mathrm{Na}^{+}, \mathrm{K}^{+}$-ATPase and carbonic anhydrase in the gerbil's vestibular system. Hear Res 43:205-218

27. Stelwagen K, Farr VC, Davis SR, Prosser CG (1995) EGTAinduced disruption of epithelial cell tight junctions in the lactating caprine mammary gland. Am J Physiol 269:R828-R855

28. Sterkers O, Ferrary E, Amiel C (1988) Production of inner ear fluids. Physiol Rev 68:1083-1128

29. Wangemann P, Liu J, Marcus DC (1995) Ion transport mechanisms responsible for $\mathrm{K}^{+}$secretion and the transepithelial voltage across marginal cells of strial vascularis in vitro. Hear Res 84:19-29

30. Zheng JL, Helbig C, Gao W-Q (1997) Induction of cell proliferation by fibroblast and insulin-like growth factors in pure rat inner ear epithelial cell cultures. J Neurosci 17:216-226

31. Zierler K, Rogus EM, Scherer RW, Wu F-S (1985) Insulin action on membrane potential and glucose uptake: effects of high potassium. Am J Physiol 249 E17-E25 